\title{
Major and Trace Element and Sr-Nd- Pb-Hf Isotope Geochemistry of the Fonualei Ridge Spreading Centre, northeast Lau Basin: Mixing between Indian upper mantle and a Samoan Plume Component
}

AVRINDER SINGH SANDHU, KAJ HOERNLE, MAXIM V. PORTNYAGIN, REINHARD WERNER, PHILIPP BRANDL AND FOLKMAR HAUFF

GEOMAR Helmholtz Centre for Ocean Research Kiel

Presenting Author: asandhu@geomar.de

Back-arc basins represent complex tectonic settings. The Fonualei Ridge Spreading Centre (FRSC), situated in the northeast Lau back-arc basin, presents an ideal place to understand varying geochemical compositions owing to Tonga subduction zone in the east and Samoan plume in the northeast. In this study we focus on the spatial geochemical variations of volcanism near the FRSC to constrain the components involved in magma generation. We present major, trace elements and $\mathrm{Nd}$, $\mathrm{Sr}, \mathrm{Pb}, \mathrm{Hf}$ isotope data for whole rocks and glasses with basaltic composition from the FRSC. Samples have relatively high $\mathrm{MgO}$ (3.06 - 13.78 wt.\%), except for the few $(\mathrm{MgO}<2.3$ wt.\%) from the southern part of the FRSC, close to the volcanic front. Samples depict enrichment in fluid mobile elements and depletion in high field strength elements, indicating subduction signature in all samples. Ratios of more fluid- to less-fluidmobile elements, such as $\mathrm{Ba} / \mathrm{Nb}$, decrease with increasing distance from the Tofua arc volcanic front. In contrast, moreincompatible to less-incompatible fluid-immobile element ratios, such as $\mathrm{Nb} / \mathrm{Y}$ ratio increase northwards towards the Samoan hotspot. The isotope data show that two major components are involved: a depleted Indian-MORB-like end member similar to the Central Lau Spreading Center lavas (representing the upper mantle) dominates in the south, whereas an enriched end member with radiogenic $\mathrm{Sr}$ and $\mathrm{Pb}$ and unradiogenic $\mathrm{Nd}$ dominates in the north. From the Nd-Hf isotope systematics, we are able to eliminate the Louisville Seamount Chain, eroded Tonga forearc and possible Hikurangi and Manihiki plateau fragments as this end member. When we combine our data with literature data from the FRSC [1], the Samoan plume seems like the most likely enriched end member. Finally, ${ }^{206} \mathrm{~Pb}^{/ 204} \mathrm{~Pb}$ vs ${ }^{208} \mathrm{~Pb} /{ }^{204} \mathrm{~Pb}$ ratio show that at least two depleted components are required, which may reflect the additional presence of a seawater-altered Pacific MORB component in the lavas closest to the trench in the south.

[1] Escrig et al., (2012), Geochemistry, Geophysics, Geosystems, 13(10). 